\title{
Review Article \\ Interactions between Myc and Mediators of Inflammation in Chronic Liver Diseases
}

\author{
Ting Liu, ${ }^{1}$ Yu Zhou, ${ }^{2}$ Kwang Suk Ko, ${ }^{3}$ and Heping Yang ${ }^{4}$ \\ ${ }^{1}$ Department of Gastroenterology, Xiangya Hospital Central South University, 87 Xiangya Road, Changsha, Hunan 410008, China \\ ${ }^{2}$ GI Liver Center, Keck School of Medicine, University of Southern California, Los Angeles, CA 90033, USA \\ ${ }^{3}$ Department of Nutritional Science and Food Management, College of Health Science, Ewha Womans University, \\ Seoul 150-750, Republic of Korea \\ ${ }^{4}$ Division of Gastroenterology, Department of Medicine, Cedars-Sinai Medical Center, Davis Building 2094A, \\ 8700 Beverly Boulevard, Los Angeles, CA 90048, USA
}

Correspondence should be addressed to Heping Yang; heping.yang@cshs.org

Received 9 October 2014; Accepted 26 November 2014

Academic Editor: Caigan Du

Copyright (C) 2015 Ting Liu et al. This is an open access article distributed under the Creative Commons Attribution License, which permits unrestricted use, distribution, and reproduction in any medium, provided the original work is properly cited.

\begin{abstract}
Most chronic liver diseases (CLDs) are characterized by inflammatory processes with aberrant expressions of various pro- and anti-inflammatory mediators in the liver. These mediators are the driving force of many inflammatory liver disorders, which often result in fibrosis, cirrhosis, and liver tumorigenesis. c-Myc is involved in many cellular events such as cell growth, proliferation, and differentiation. $\mathrm{c}-\mathrm{Myc}$ upregulates IL- 8 , IL-10, TNF- $\alpha$, and TGF- $\beta$, while IL- 1 , IL-2, IL-4, TNF- $\alpha$, and TGF- $\beta$ promote c-Myc expression. Their interactions play a central role in fibrosis, cirrhosis, and liver cancer. Molecular interference of their interactions offers possible therapeutic potential for CLDs. In this review, current knowledge of the molecular interactions between c-Myc and various well known inflammatory mediators is discussed.
\end{abstract}

\section{Introduction}

Chronic liver diseases (CLDs) are an important cause of morbidity and mortality worldwide. Moreover, the burden of CLDs is projected to increase. Inflammatory cytokines are a group of important regulatory mediators involved in the development of CLDs. The development and progression of CLDs are associated with hepatitis B, hepatitis C, alcoholic liver disease, drug-induced liver disease, autoimmune liver disease, hepatocellular carcinoma (HCC), and cholangiocarcinoma (CCA).

c-Myc can be heterodimerized with Max to transactivate its target genes through binding the consensus sequence E box within the promoter region [1-3]. c-Myc has been implicated in regulating a wide variety of biological processes, including division, apoptosis, cellular growth, and angiogenesis $[4,5]$. We will summarize the interaction of inflammatory mediators with c-Myc in CLDs. Although NF- $\kappa$ B and AP1 are not inflammatory mediators, they play key roles in the interaction of c-Myc and inflammatory mediators. We will also discuss their links with inflammatory mediators and c-Myc. Furthermore, we will discuss the relevance of inflammatory mediators and c-Myc for liver diseases and for the development of anti-CLD strategies.

\section{Inflammatory Mediators}

2.1. IL-1. IL-1 is an important upstream proinflammatory cytokine that affects immunity and hematopoiesis by inducing cytokine cascades. IL-1 mediates inflammation mainly by inducing a local cytokine network, enhancing inflammatory cell infiltration, and augmenting adhesion molecule expression on endothelial cells (ECs) and leukocytes [6].

IL- $1 \beta$, one of the major agonists of IL-1, is only active in its processed, secreted form and mediates inflammation, promoting invasiveness, immunosuppression, and tumorigenesis [7]. IL-1 $\beta$ is a potent inflammatory cytokine mainly produced by macrophages. Toll-like receptors (TLRs) play a critical role in innate immune responses. IL- $1 \beta$ production requires stimulation by TLR ligands as well as a second signal 
TABLE 1

\begin{tabular}{|c|c|c|c|}
\hline Liver diseases & & Inflammatory mediator expressions & References \\
\hline \multirow{2}{*}{$\begin{array}{l}\text { Chronic hepatitis B and } \\
\text { hepatitis C }\end{array}$} & Up & IL-1a, IL- 4 , IL-6, IL-8, IL-10, c-Jun, IFN- $\gamma$, TGF- $\beta$, and TNF- $\alpha$ & \multirow{2}{*}[120-124]{} \\
\hline & Down & IL-2 & \\
\hline Cholangiocarcinoma & Up & IL-6, TGF- $\beta$, and TNF- $\alpha$ & {$[41,125]$} \\
\hline \multirow{2}{*}{ Alcoholic hepatitis } & Up & IL-1, IL-4, IL-6, IL-8, TGF- $\beta$, and TNF- $\alpha$ & \multirow{2}{*}[126,127]{} \\
\hline & Down & IL-10 & \\
\hline Hepatocellular carcinoma & Up & IL-6, IL-8, IL-10, c-fox, c-Jun, NF- $\kappa$ B, TGF- $\beta$, and TNF- $\alpha$ & {$[122,128-131]$} \\
\hline \multirow{2}{*}{ Primary biliary cirrhosis } & Up & IL-1, IL-2, IL-6, IL-8, IL-10, c-fox, c-Jun, IFN- $\gamma$, NF- $\kappa$ B, TGF- $\beta$, and TNF- $\alpha$ & \multirow{2}{*}[122,129,130,132-135]{} \\
\hline & Down & IL-10 & \\
\hline $\begin{array}{l}\text { Infantile cholestatic hepatitis } \\
\text { syndrome }\end{array}$ & Up & IL-6, TNF- $\alpha$ & [136] \\
\hline Injury of liver & Up & IL-1 $\beta$, IL-6, IL-8, and TNF- $\alpha$ & {$[45,137]$} \\
\hline
\end{tabular}

such as muramyl dipeptide- (MDP-) mediated stimulation of NOD-like receptors (NLR) or P2X7 receptors [8]. IL-1 $\beta$ is involved in nonalcoholic fatty liver disease and alcoholic steatohepatitis [9-12].

Hepatic stellate cells (HSCs) are key players in fibrogenesis in chronic liver diseases. In HSCs, IL- $1 \beta$ mediates the upregulation of fibrogenic tissue inhibitor of metalloproteinase-1 (TIMP-1) and the downregulation of bone morphogenetic protein and activin membrane-bound inhibitor (BAMBI) [1]. Moreover, IL-1 $\beta$ promotes the survival of activated HSCs in mice [13]. Overexpression of IL- $1 \beta$ triggers spontaneous liver injury and fibrosis [14].

Several oncogenes, including Myc and Ras, both mediate neoplastic transformation and activate inflammatory cytokines that establish the proinvasive tumor microenvironment [15]. Myc activation in pancreatic $\beta$ cells rapidly induces the expression and release of the proinflammatory cytokine IL- $1 \beta$. IL- $1 \beta$ inhibition significantly inhibits and delays Myc activation of islet angiogenesis, confirming the key role of IL- $1 \beta$. IL- $1 \beta$ is the principal Myc effector responsible for triggering rapid onset of islet angiogenesis [16]. IL- $1 \beta$ directly affects the survival and proliferation of endothelial cells and promotes the induction of other proangiogenic factors such as matrix metalloproteinases (MMPs), TGF- $\beta$, TNF- $\alpha$, angiopoietin-1, IL-6, and vascular endothelial growth factor (VEGF) A $[17,18]$. Myc plays an important role in the PI3Kmediated VEGF regulation in neuroblastoma (NB) cells [19]. $\mathrm{c}-\mathrm{Myc}$ is essential for vasculogenesis and angiogenesis during development and tumor progression. This effect is partially associated with a requirement for $\mathrm{c}-\mathrm{Myc}$ in VEGF expression. However, c-Myc is also required for the proper expression of other angiogenic factors, including angiopoietin-1 [20]. In a transgenic model of Myc-dependent carcinogenesis such as pancreatic $\beta$ cells, IL- $1 \beta$ is both necessary and sufficient to mediate Myc-induced release of VEGF and onset of islet neoangiogenesis.

IL-1 expression increases in alcoholic hepatitis and cirrhosis. IL-la expression is increased in chronic hepatitis B and hepatitis $\mathrm{C}$, while IL- $1 \beta$ expression rises in alcoholic liver injury (Tables 1 and 2). IL-1 $\beta$ and IL-1 increase cMyc expression while IL-1 increases IL-1 $\beta$ mRNA expression (Figure 1(A)).

2.2. IL-2. IL-2 is a pleiotropic cytokine secreted by lymphocytes that stimulates the proliferation of mucosal lymphocytes, natural killer cells, and macrophages [21]. It can also promote $\mathrm{B}$ cell antibody production and proliferation [22] and is essential for activation-induced cell death, important in homeostasis and eliminating potentially harmful autoreactive cells [23].

Many studies confirm that IL-2 receptors are expressed in the surface of many tumor cells, a feature that when combined with IL-2 could inhibit tumor cell growth [24, 25]. The spleen tyrosine kinase and protein tyrosine kinase (SykPTK) is physically associated with IL-2R in peripheral blood lymphocytes [26]. Therefore, SykPTK may be an integral signaling molecule engaged by the IL-2R. It has been identified that SykPTK plays a role in mediating IL-2-induced expression of $\mathrm{c}-\mathrm{Myc}$ and subsequent cellular proliferation. There are two IL-2 receptor-dependent signaling pathways; one is the c-Fos/c-Jun induction pathway mediated by src family protein tyrosine kinases while the other is the c-Myc induction pathway [27]. Genistein decreases expression of rat c-Myc mRNA, which is increased by IL-2 [28]. The IL-2/IL$2 \mathrm{R}$ interaction causes c-Myc overexpression and cytochrome P450 (CYP) downregulation in cultured rat hepatocytes [29, 30].

IL-2 increase is associated with hepatic fibrosis in humans [31]. IL-2 directly increased c-Myc mRNA expression in rat hepatocytes and indirectly promoted c-Myc expression through activation of $\mathrm{c}$-Jun in $\mathrm{T}$ cells from chronically infected HIV+ patients. c-Jun expression increased when bound to the AP-1 response element of a mouse c-Myc promoter. Even though IL-2 expression decreases in patients with chronic HBV and HCV infection, its expression increases in those with cirrhosis (Tables 1 and 2). IL-2 promotes c-Myc expression and a positive interaction between IL-2RA and IL2 (Figure 1(B)). 
TABLE 2

\begin{tabular}{|c|c|c|c|}
\hline Genes & Functions & Expression in chronic liver diseases & References \\
\hline IL-1 & It activates $\mathrm{T}$ and $\mathrm{B}$ cells and monocytes & Up & {$[123,132,135,138]$} \\
\hline IL-2 & $\begin{array}{l}\text { It is necessary for the growth, proliferation, and differentiation of } \\
\text { thymic-derived lymphocytes (T cells) }\end{array}$ & Up, down & [133] \\
\hline IL-4 & It induces secretion of Ig by B cells, pleiotropic effect on T cells & Up & [123] \\
\hline IL-6 & $\begin{array}{l}\text { It is an important mediator of fever and of the acute phase response and } \\
\text { stimulates thymocyte proliferation and fibroblast growth factor activity }\end{array}$ & Up & {$[137,139]$} \\
\hline IL-8 & $\begin{array}{l}\text { It acts as neutrophil chemotactic factor and can induce chemotaxis in } \\
\text { target cells, primarily neutrophils, and also other granulocytes, causing } \\
\text { them to migrate toward the site of infection }\end{array}$ & Up & {$[120,128,134]$} \\
\hline IL-10 & $\begin{array}{l}\text { It stimulates proliferation of B cells, thymocytes, and mast cells, } \\
\text { stimulates IgA production by B cells, and also enhances B cell survival }\end{array}$ & Up, down & {$[123,124,138]$} \\
\hline Jun & $\begin{array}{l}\text { It is intronless and is mapped to } 1 \mathrm{p} 32-\mathrm{p} 31 \text {, a chromosomal region } \\
\text { involved in both translocations and deletions in human malignancies }\end{array}$ & Up & [124] \\
\hline $\mathrm{NF}-\kappa \mathrm{B}$ & $\begin{array}{l}\text { Upon activation of either } \mathrm{T} \text { or } \mathrm{B} \text { cell receptor, it upregulates genes } \\
\text { involved in } \mathrm{T} \text { cell development, maturation, and proliferation }\end{array}$ & Up & {$[130]$} \\
\hline TGF- $\beta$ & It suppresses $\mathrm{T}$ cell growth and differentiation & Up, down & {$[121,139]$} \\
\hline TNF- $\alpha$ & $\begin{array}{l}\text { It is an adipokine involved in systemic inflammation, is a member of a } \\
\text { group of cytokines that stimulate the acute phase reaction, and is a } \\
\text { mediator of immune functions in the regulation of immune cells }\end{array}$ & Up, down & [140] \\
\hline
\end{tabular}

(E) Interaction between IL-8,

(C) Interaction between IL-4,

(A) Interaction of Myc,

$$
\text { IL-1, and IL-1 } \beta
$$
NF- $\kappa$ B, p53, and c-Myc

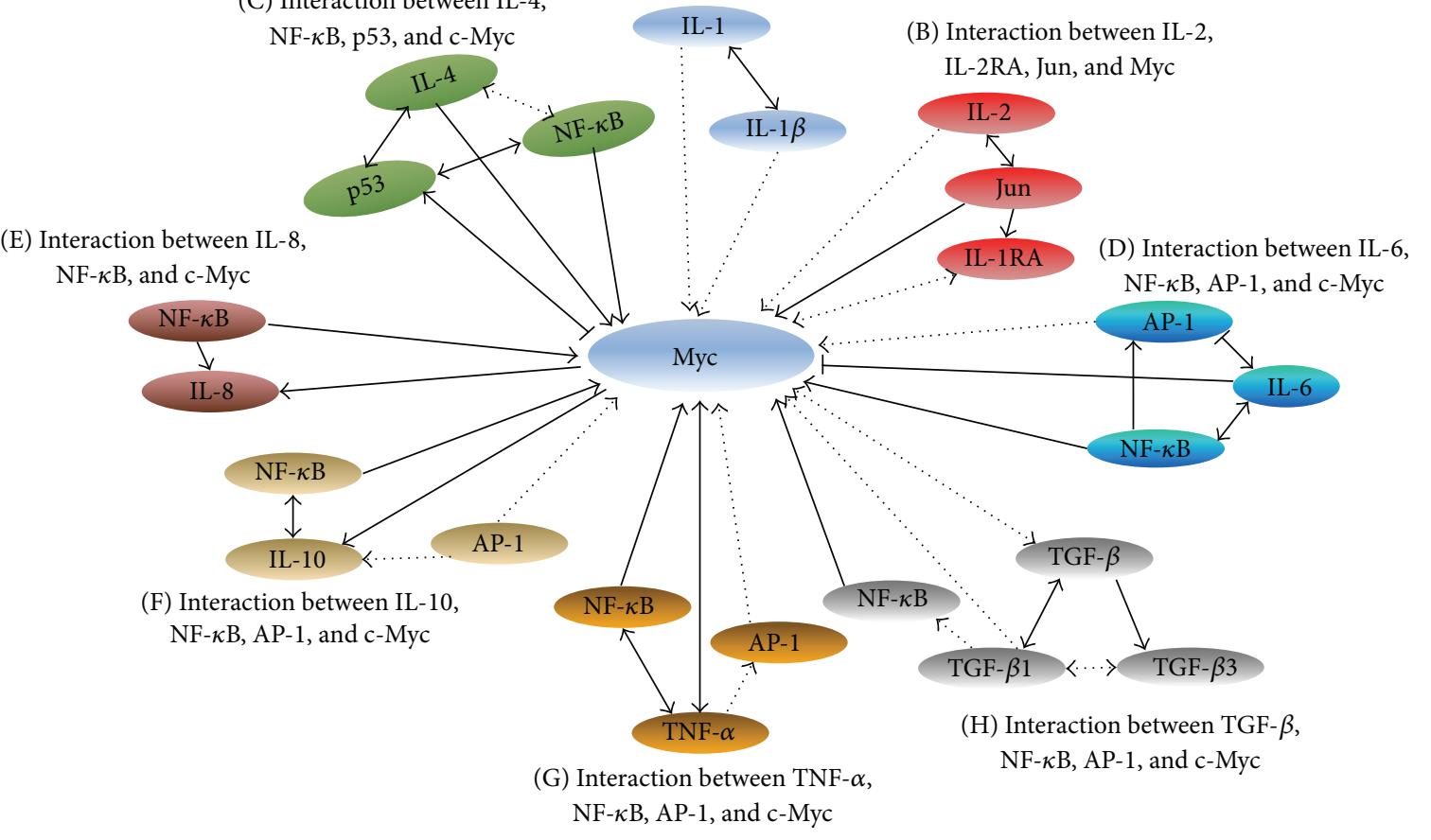
$\mathrm{NF}-\kappa \mathrm{B}$, and $\mathrm{c}-\mathrm{Myc}$

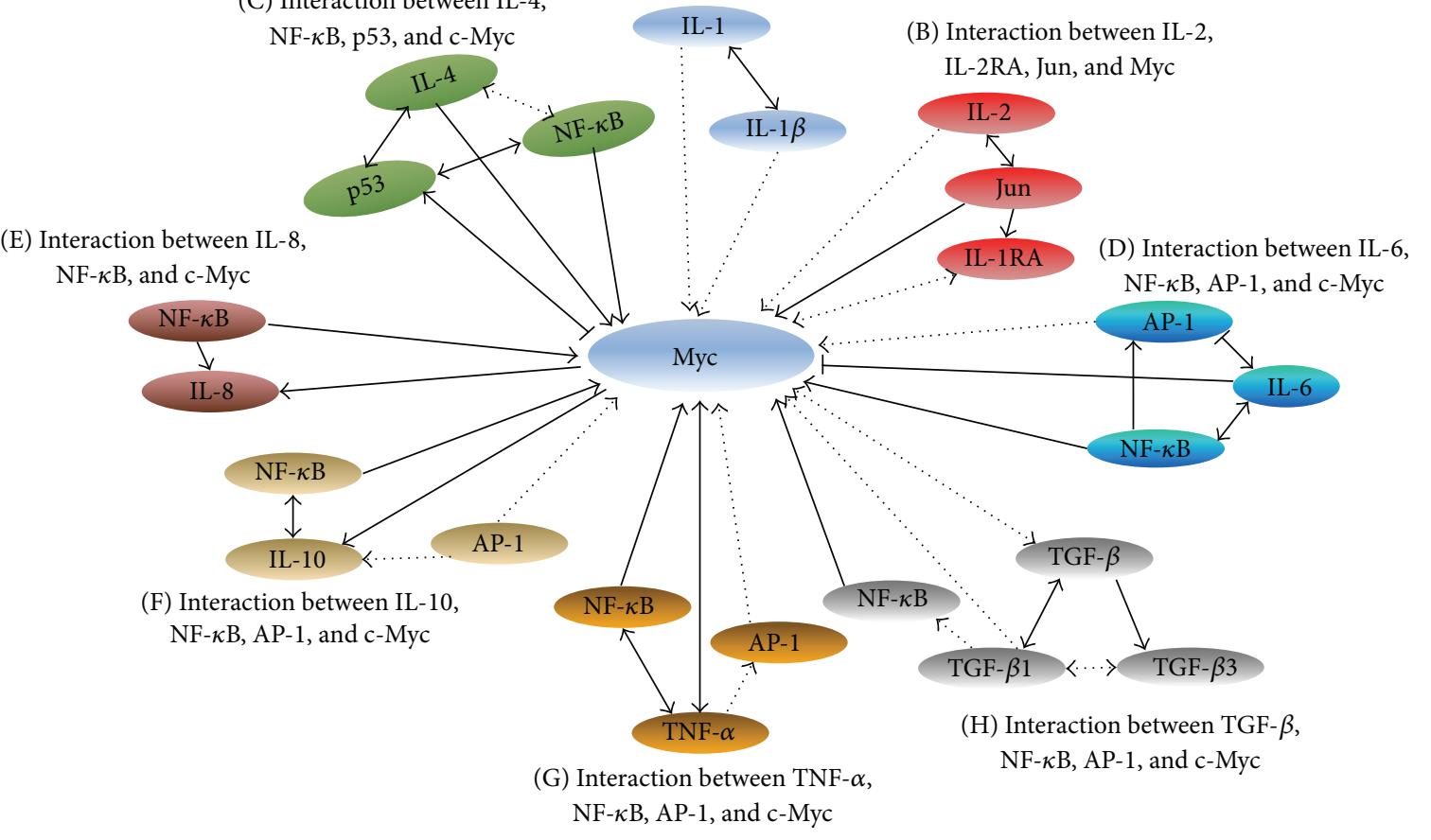

FIGURE 1: The interaction between Myc and mediators of inflammation. Arrow = positive regulation, Dot arrow = positive regulation with unclear mechanisms. Arrows in beginning and end = regulation of each other positively. Bar = negative regulation. IL-2RA: interleukin 2 (IL-2) receptor alpha. (A) Interaction of Myc, IL-1, and IL-1 $\beta$. (B) Interaction between IL-2, IL-2RA, Jun, and Myc. (C) Interaction between IL-4, NF- $\kappa$ B, p53, and c-Myc. (D) Interaction between IL-6, NF- $\kappa$ B, AP-1, and c-Myc. (E) Interaction between IL-8, NF- $\kappa$ B, and c-Myc. (F) Interaction between IL-10, NF- $\kappa$ B, AP-1, and c-Myc. (G) Interaction between TNF- $\alpha$, NF- $\kappa$ B, AP-1 and c-Myc. (H) Interaction between TGF- $\beta$, NF- $\kappa$ B, and c-Myc. 
2.3. IL-4. IL-4 is a multifunctional pleiotropic cytokine produced mainly by activated $\mathrm{T}$ cells and also by basophils, mast cells, and eosinophils, in response to receptor-mediated activation events. IL-4 plays a critical role in defining the Th2 phenotype of lymphocytes and in regulating cell proliferation, apoptosis, and the expression of numerous genes in various cell types, including macrophages, lymphocytes, fibroblasts, and epithelial and endothelial cells $[32,33]$.

Poly (ADP-ribose) polymerase (PARP)14 is an ADP ribosyltransferase expressed in B lymphocytes [34]. PARP14 interacts with signal transducers and activators of transcription (STAT) 6. PARP14 is required in IL-4 enhanced glycolysis in B cells, a process central to the role of PARP14 in IL-4-induced survival. PARP14 contributes to Myc-induced lymphoma pathobiology [34]. Both IL-4 and IGF-I can induce an early $\mathrm{c}-\mathrm{Myc}$ response gene expression. IL-4 synergizes with IGFI for hematopoietic cell proliferation, likely through cross talk between SHC/Grb2/MAPK and STAT6 pathways and through c-Myc gene upregulation [35]. IL-4 can promote human embryonic stem cells differentiation into "fibrogenic" fibroblast-like cells [36]. IL-4 can increase expression of cMyc mRNA in tumor-associated macrophages and promote its translocation to the nucleus [37].

Deregulated IL-4 expression leads to direct or indirect activation of c-Myc (Figure 1(C)). Aberrant IL-4 expression is associated with HBV and HCV infection, alcoholic hepatitis, primary biliary cirrhosis (PBC), and chronic hepatitis in humans $[38,39]$ (Tables 1 and 2). It is interesting to characterize how IL-4-mediated c-Myc expression is involved in molecular patterns of IL-4-c-Myc, IL-4-NF- $\kappa$ B-c-Myc, or IL4-p53-c-Myc in CLDs.

2.4. IL-6. IL-6, both an immunomodulatory factor and an inflammatory mediator, could stimulate cell growth and extracellular matrix proliferation [40]. IL-6 has been identified as a central factor in liver inflammation, which leads to liver epithelial changes. IL-6 significantly increases in liver epithelia in response to stimulation and inflammatory mediators, such as endotoxin and TNF- $\alpha$ [41].

IL-6 can enhance the translation of c-Myc in multiple myeloma cells [42]. Moreover, IL-6 can promote c-Myc expression and cultured vascular smooth muscle cell proliferation [43]. The acute phase response is an inflammatory process dominated by the cytokine IL- 6 . STAT3 activation transduces IL-6 signaling, which induces the production of acute phase proteins such as fibrinogen and haptoglobin. IL-6 could enhance c-Myc protein expression in multiple myeloma cells independent of any effect on Myc transcription [42]. Also, IL-6 can reverse CD33 expression by upregulating Myc and subsequently downregulating CCAAT/enhancer binding protein (CEBPA) expression in myeloma cells [43].

Upregulation of human IL-6 protein is associated with infantile hepatitis syndrome, cholestasis subtype, alcoholic hepatitis, chronic hepatitis B and hepatitis C infection [29, $44,45]$, cirrhosis, CCA, HCC, and experimental liver injury (Tables 1 and 2). c-Myc expression is activated by IL-6-c-Myc and IL-6-AP-1-c-Myc pathways while it is suppressed by the IL-6-NF- $\kappa$ B-c-Myc pathway (Figure 1(D)).
2.5. IL-8. IL-8 is a readily activated small molecule polypeptide secreted by a variety of immune cells such as monocytesmacrophages, T lymphocytes, neutrophils, and HBV-infected liver cells. Cholangiocytes can produce IL-6, IL-8, TGF$\beta$, TNF- $\alpha$, and platelet-derived growth factor (PDGF) B chain $[46,47]$. These cytokines can lead to cellular injury by stimulating an immune response and promoting tissue fibrosis. Cholangiocytes are highly responsive to Toll-like receptor (TLR) agonists [48]. Interaction of cholangiocytes with lymphocytes, HSC, and portal fibroblasts contributes to chronic inflammation and fibrosis in cholestatic liver disease [49]. c-Myc expression increases in the cholestasis-associated CCA and cholestatic liver injury $[1,2]$. IL-8 is activated in patients with CLDs [50-52].

Opisthorchis viverrini (OV) has been reported to be an important risk factor of HCC and CCA [53]. It has been found that the secreted/excreted products of OV can induce IL-8 expression and secretion, which is a primary event in opisthorchiasis and CCA pathogenesis [54]. HBV infection can activate the immune system to induce liver cell synthesis of a large number of TNF- $\alpha$ [55], which also induces liver cells production of many IL-6 and IL-8, leading to liver inflammation and liver cell injury [56].

Hypoxia has been implicated in the pathogenesis of a broad range of liver diseases, especially in HCC and CCA $[1,53]$. Gene expression regulated by hypoxia inducible factor (HIF) $\alpha$ subunits is currently very interesting due to the interaction of HIF- $1 \alpha / \mathrm{HIF}-2 \alpha$ and c-Myc/Max proteins. HIF- $2 \alpha$ increases c-Myc activity by stabilizing the c-Myc:Max complex, which promotes cell cycle progression. However, HIF- $1 \alpha$ inhibits the c-Myc function and cell proliferation [57]. Since HIF- $1 \alpha$ binds to the Max protein, it competes with c-Myc and inhibits c-Myc protein stability [58]. HIF-1 $\alpha$ downregulates IL-8 expression via attenuation of the Nrf2 transcription factor expression and activity in human endothelial cells [59]. Moreover, inactivation of Mxil (for Max interactor 1) induces IL-8 secretion activation in polycystic kidneys [60]. Nrf2 and c-Myc attenuation downregulates IL-8 expression in hypoxia [61].

IL-8 increase is associated with chronic hepatitis B and hepatitis $\mathrm{C}$, alcoholic hepatitis, CCA, HCC, and experimental liver injury (Tables 1 and 2). Upregulation of human IL-8 protein in serum is also associated with human liver cirrhosis while upregulating transgenic c-Myc protein in mouse liver increases progression to hepatocarcinoma in mice $[62,63]$. Upregulation of IL-8 is associated with Myc-IL- 8 and NF- $\kappa$ BMyc-IL-8 circuitry (Figure 1(E)).

2.6. IL-10. IL-10 is a negative regulator mainly secreted by Th2 cells, activated B cells, monocytes, and macrophages. It helps regulate immune and inflammatory responses and tumorigenesis. IL-10 is an important anti-inflammatory mediator essential for attenuating inflammatory responses. For example, mice lacking IL-10 are more likely to die from excessive inflammatory responses when exposed to bacterial pathogens. JAK2 inhibition induced apoptosis required the inhibition of autocrine IL-10 and c-Myc expression [64]. In addition, Myc inactivation correlated with elevated levels of IL-10 receptor, causing dormancy in murine two-hit B 
lymphomas [65]. Transgenic c-Myc and mTOR-activated signaling increase mouse IL-10 expression in serum from mice exhibiting anorexia-cachexia [66]. IL-10 decreases regeneration of liver and inflammatory liver injury [32, 45].

The Ser/Thr protein kinase mammalian target of rapamycin (mTOR) critically regulates cell growth, proliferation, apoptosis, and metabolism. mTOR pathway inhibition downregulated renal tissue p53 expression [67]. Hypoxia induced p53, especially in the IL-10 [68]. A physical association between mTOR and the transcription factor signal transducer and activator of transcription-1 (STAT1) was recently identified in human cells, suggesting a similar role for mTOR in interferon- $\gamma$-stimulated gene transcription. mTOR inactivation enhanced its association with STAT1 and increased STAT1 nuclear content in PP2Ac-dependent fashion [69] while STAT1 could also regulate IL-10 and Myc.

Upregulation of IL-10 is associated with chronic HBV and $\mathrm{HCV}$ infection and HCC. IL-10 downregulation is related to alcoholic hepatitis (Tables 1 and 2). The interaction of IL-10 and c-Myc pathways includes Myc-IL-10, NF- $\kappa$ B-Myc-IL-10, and AP-1-Myc-IL-10 (Figure 1(F)).

2.7. TNF- $\alpha$. TNF- $\alpha$ is an adipokine involved in systemic inflammation and belongs to a group of cytokines that stimulate the acute phase reaction. TNF- $\alpha$ regulates immune and inflammatory responses, tissue remodeling, cell motility, cell cycle, and apoptosis. TNF- $\alpha$ is one of the major inflammatory mediators in liver fibrosis and a major contributor of alcoholic liver disease. TNF- $\alpha$ and its cognate receptors activate the JNK (c-Jun N-terminal kinase) pathway signaling cascade. JNK has been found to promote cell survival by regulating c-Jun and cell death by regulating $\mathrm{c}-\mathrm{Myc}$ and p53 activity. Other researches [70] also found that long term elevated levels of TNF- $\alpha$ increase the tendency toward malignant transformation in mesenchymal stem cells (MSCs) through NF- $\kappa$ B-mediated upregulation of the oncogenes $c$ Myc and c-Fos. Dysregulation of TNF- $\alpha$ production has been implicated in a variety of human diseases such as CLDs.

TNF- $\alpha$ regulates $c-M y c$ expression in a cell-type specific manner. TNF- $\alpha$ treatment could markedly induce the expression of gene c-Myc and cyclin D1 in cancer cells [71]. TNF-resistant cells could overexpress c-Myc in $\mathrm{C} 3 \mathrm{H}$ mouse embryo fibroblasts [72]. TNF- $\alpha$ has been shown to downregulate the expression of c-Myc in HL60 cells [73].

2.8. TGF- $\beta$. TGF- $\beta$ is a pleiotropic cytokine with key roles in development, immunity, wound healing, and carcinogenesis [74]. Hepatic macrophages can produce TGF- $\beta$, which promotes myofibroblast fibrogenesis. TGF- $\beta$ not only mediates its profibrotic actions by stimulating hepatic stellate cells (HSCs) through Smad-dependent pathways, but also represses HSC proliferation. HSCs also produce TGF- $\beta$ to a lesser degree. TGF- $\beta$ upregulation occurred in chronic HBV and HCV infection, alcoholic hepatitis, PBC, HCC, and CCA (Tables 1 and 2).

TGF- $\beta$ could induce Myc expression by stimulating Smad3 [75]. It has been found that Helicobacter infection led to increased production of TNF- $\alpha$ in colonic tissue from
Smad3-/- mice [76]. As mentioned above, Myc interacts with E2F1, which could be induced by Kruppel-like factor 6 (KLF6). Moreover, KLF6 could stimulate TGF- $\beta 1$. The cMyc expression in fibroblasts is initially repressed by TGF- $\beta$, but subsequent cyclin D1/cyclin-dependent kinase 4 (CDK4) goes through a complete functional change to stimulate $\mathrm{c}$ Myc. TGF- $\beta$ inhibits cell growth by downregulating c-Myc via the Smad2 phosphorylation at the $\mathrm{C}$-terminal regions (pSmad2C and pSmad3C) pathways [77].

\section{Key Players Link c-Myc and Mediators of Inflammation}

3.1. $N F-\kappa B$. NF- $\kappa \mathrm{B}$ appears to play a major role in the network regulation of inflammatory genes and Myc. NF$\kappa \mathrm{B}$ is composed of $\mathrm{c}-\mathrm{Rel}, \operatorname{RelA}(\mathrm{p} 65), \operatorname{RelB}, \mathrm{NF}-\kappa \mathrm{B} 1(\mathrm{p} 50)$, and NF- $\kappa \mathrm{B} 2(\mathrm{p} 52)$. The five subunits share a conserved $\mathrm{N}-$ terminal domain that mediates DNA binding, dimerization, and nuclear import. It also has been found that murine $\mathrm{c}$ $\mathrm{Myc}$ is a direct transcriptional target of Rel/NF- $\kappa \mathrm{B}$, which upregulates c-Myc. B cells lacking p50 and c-Rel fail to increase in size upon mitogenic stimulation due to reduced induction in $\mathrm{c}-\mathrm{Myc}$ expression. NF- $\kappa \mathrm{B}$ activation pathways have type 1 (p50-dependent) and type 2 (p52-dependent) pathways. While LPS and B cell activation factor (BAFF) mainly activate the type 1 or type 2 pathways, respectively, CD40 ligand (CD40L) strongly activates both [78]. c-Myc was induced in anti-CD40 and LPS treatment group. NF$\kappa \mathrm{B}$ knockout in mice and c-Rel knockout in mice decrease expression of mouse $c-M y c$ mRNA in primary B lymphocytes. NF- $\kappa \mathrm{B}$ increases regulation of the $\mathrm{c}-\mathrm{Myc}$ promoter upstream regulatory element [79].

Peroxisome proliferator-activated receptor gamma $(\operatorname{PPAR} \gamma)$ expression is involved in macrophage inflammatory responses, $\mathrm{T}$ cell proliferation, cytokine production, and $\mathrm{B}$ cell proliferation as well as immune regulation. PPAR-gamma can inhibit HSC proliferation, hepatic fibrosis [80], and HCC metastases in vitro and in mice [81]. Liver-specific PPAR $\gamma$ deficiency improves fatty liver in ob/ob mice [82]. PPAR- $\kappa$ may be an important molecule in mediating NF- $\kappa \mathrm{B}$ and Myc expression. PPAR $\gamma$ agonists activated NF- $\kappa \mathrm{B}$ (p50, Rel A, and $c$-Rel) binding to the upstream NF- $\kappa \mathrm{B}$ regulatory element site of c-Myc [83]. PPAR $\gamma$ agonists increased binding of a DNA fragment containing an upstream NF- $\kappa \mathrm{B}$ regulatory element from c-Myc gene and mouse p50 protein [84].

P65 can mediate c-Myc expression. Using the inducible c-MycER system and c-Myc null fibroblasts found c-Myc expression significantly inhibited p65-mediated transactivation [85]. $c-M y c$ expression inhibited NF- $\kappa \mathrm{B}$ activation by interfering with p65 transactivation. They also found c-Myc expression could not inhibit the transactivation potential of p65. Their studies suggest that c-Myc attenuated NF- $\kappa$ B transcription by impairing p65 transactivation and subsequently sensitized cells to TNF-mediated apoptosis. Furthermore, cMyc protein decreases transcriptional activator activation of human p65 increased by TNF protein. P65 and p50 can transactivate the $\mathrm{c}-\mathrm{Myc}$ promoter [86]. Blocking p65 protein synthesis with specific antisense oligonucleotides greatly reduced carcinoma cell growth rate [87]. The inhibitory 
effect seems to be mediated by the suppression of c-Myc gene expression, since treatment with antisense oligonucleotides for $\mathrm{p} 65$ gene interfered negatively with c-Myc gene expression. p65 antisense decreases human c-Myc mRNA expression. NF- $\kappa \mathrm{B} /$ Rel transcription factors could regulate many genes including the c-Myc oncogene [87]. There is a relationship between the $\mathrm{p} 65$ and aryl hydrocarbon receptor (AhR) [88]. AhR and RelA increase c-Myc protein expression. This relationship activates c-Myc gene transcription in breast cancer cells. In transient cotransfection, p65 and AhR gene products demonstrated cooperation in transactivating the cMyc promoter, which was dependent on the NF- $\kappa$ B elements, and in inducing endogenous c-Myc protein levels. Thus, p65 participated in the expression of c-Myc gene.

It has been reported that transgenic c-Myc in mouse liver increases formation to hepatocarcinoma in mice [63, 89]. Mutant human c-Met and c-Myc also increase mouse hepatocarcinoma formation [90]. c-Myc gene knockout decreases size of hepatocytes [91] and decreases ploidy of hepatocytes in mouse liver [92]. p50/p105 knockout decreases hepatocytes proliferation in livers from mice treated with diethylnitrosamine [93]. In 129S1/Sv mouse, NF- $\kappa$ B knockout increases liver inflammation in mice [94]. p50 knockout increases liver injury in mice, which involve T. congolensevariant antigen type 13 [95]. Thus, it has been discovered that both c-Myc and v-Myc can induce a truncated form of the p65, RelA(p37) [96]. More and more data demonstrate that transcriptional repression of NF- $\kappa \mathrm{B}$ can be mediated by $\mathrm{c}-$ Myc under certain physiological circumstances $[97,98]$.

3.2. AP-1. c-Myc gene overexpression is implicated in HCC in the hepadnavirus-infected woodchucks [99], ground squirrels [100], cholestasis-accelerated CCA [1], and LCAmediated liver injury [101]. In chronic diseases, c-Myc overexpression may significantly predispose the liver to hepatocarcinogenesis [102]. In general, c-Myc promotes a cell survival unless exposed to environmental stress such as enforced cMyc overexpression.

c-Fos, which heterodimerizes with c-Jun, leads to a more stable AP-1 complex that increases the capacity of c-Jun to transactivate target genes. c-Myc expression requires phosphorylation and nuclear translocation of extracellular signalregulated kinase (ERK), which produces c-Fos phosphorylation and forms a specific AP-1 [103]. c-Fos downregulation in dysplastic liver nodules is associated with the initiation stage of liver cancer in humans [104]. Deletion analysis of the promoter region of the c-Fos gene indicated that the ATF2 responsive element conferred the Myc-induced expression of c-Fos [105]. Coexpression of the dominant-negative mutants of c-Fos, p38, and Racl blocked the Myc-mediated apoptosis [105]. Moreover, hepatitis B virus X protein (HBx) helps downregulate human c-Fos protein increased by mouse cMyc protein. Thus, c-Fos could be a mediator of c-Mycinduced apoptosis.

The c-Jun NH2-terminal kinase (JNK) and c-Jun in the liver play an important role in growth regulation via the JNK pathway. Both c-Jun-deficient mice $[106,107]$ and JNK1-deficient mice [108] exhibit major defects in liver regeneration following partial hepatectomy. Furthermore, both c-Jun-deficient mice and JNK1-deficient mice were protected against the development of HCC following exposure to the carcinogen diethylnitrosamine (DEN) $[108,109]$. Even though the mechanism of JNK and c-Jun signaling in the liver that contributes to regeneration and HCC is unclear, downregulation of the proliferation inhibitor p21CIP1 and upregulation of c-Myc appear to be critical factors $[107,108]$.

\section{Summary}

IL-1 receptor antagonist is considered an independent marker of nonalcoholic steatohepatitis in humans [110]. Since IL$1 \beta$ levels increase in patients with alcoholic liver disease (ALD), further studies should focus on defining regulatory mechanisms in which IL-1, IL-1 $\beta$, and c-Myc on various cell types affect multiple cellular responses in ALD.

Elevated circulating soluble IL-2 receptors in patients with chronic liver diseases are associated with nonclassical monocytes [111]. This may not only improve our understanding of how IL-2 regulates c-Myc expression, but also allow us to focus therapeutic efforts on this downstream transcriptional master-c-Myc in the monocytes.

Drug-induced liver injury (DILI) can lead to significant patient morbidity and mortality [112]. IL-4 plays a prominent role in mediating toxicity. Hepatocyte culture DILI model will improve our understanding of how IL-4 regulates c-Myc expression and help to find therapeutic targets.

IL-8 levels increase in CLDs, especially in patients in end-stage cirrhosis and patients with cholestatic diseases. Intrahepatic IL-8 upregulation could be associated with neutrophil infiltration in patients with PBC [53]. Increased IL-8 levels were associated with hepatic macrophage accumulation in noncholestatic cirrhosis. Monocyte-derived macrophages from CLD patients, especially the nonclassical CD16+ subtype, displayed enhanced IL-8 secretion in vitro. Interestingly, IL-8 correlated with liver function, inflammatory cytokines, and noninvasive fibrosis markers [53]. c-Myc regulation represents a novel anti-IL-8 therapy for use in inflammatory liver disease.

IL-10 may play a dual role in controlling liver injury via proinflammatory cytokine TNF- $\alpha$ inhibition and ethanolinduced steatosis, leading to potentiating alcoholic liver injury and ameliorating alcoholic liver injury, or via the inhibition of the hepatoprotective cytokine IL-6 [113]. In fact, $\mathrm{c}$-Myc may play an important role in regulating liver injury (Figure 1(F)). Adjusting c-Myc expression may provide a novel anti-IL-10 therapy for use in alcoholic liver injury.

Alcoholic hepatitis, chronic hepatitis B and hepatitis C, cirrhosis, CCA, HCC, and experimental injury of liver can increase TNF- $\alpha$ expression (Tables 1 and 2). On one hand, $\mathrm{c}-\mathrm{Myc}$ promotes TNF- $\alpha$ expression, and on the other hand, TNF- $\alpha$-NF- $\kappa$ B-Myc-TNF- $\alpha$ and TNF- $\alpha$-AP-1-MycTNF- $\alpha$ pathways activate TNF- $\alpha$ (Figure $1(\mathrm{G})$ ). However, anti-TNF- $\alpha$ agents potentially cause DILI [114].

TGF- $\beta$ is a key regulator in CLDs, contributing to all stages of disease progression from initial liver injury through inflammation and fibrosis to cirrhosis and HCC [115]. TGF$\beta$ interacts with multiple important pathways, such as NF$\kappa \mathrm{B}, \mathrm{AP} 1$, and $\mathrm{c}-\mathrm{Myc}$ (Figure $1(\mathrm{~F})$ ). Since TGF- $\beta$ expression is 
dominant in liver macrophages and low in HSCs, target TGF$\beta$ signaling should focus on the right cell type at the right time during CLD development.

The NF- $\kappa \mathrm{B}$ signaling pathway is particularly relevant to hepatitis (liver infection by Helicobacter, viral hepatitis induced by $\mathrm{HBV}$ and $\mathrm{HCV}$ ), liver fibrosis, cirrhosis, and HCC. The NF- $\kappa \mathrm{B}-\mathrm{c}-\mathrm{Myc}$ signaling pathway is a potential target to develop hepatoprotective agents. Although several types of drugs including IKK inhibitors, antioxidants, selective estrogen receptor modulators (SERMs), proteasome inhibitors, and nucleic acid-based decoys have been demonstrated to interfere with $\mathrm{NF}-\kappa \mathrm{B}$ activity at different levels, some of the drugs also influence c-Myc activity. The hepatoprotective agents for targeting NF- $\kappa \mathrm{B}-\mathrm{c}-\mathrm{Myc}$ molecular patterns need to be taken into consideration during development of new therapeutic regimens.

AP-1 plays an important role in the development of HCC [116]. AP-1 is involved in dietary obesity, hepatic lipid metabolism, and NAFLD $[117,118]$. A selective AP-1 inhibitor T-5224 [119] has been investigated in phase II human clinical trials. Nevertheless, no effective AP-1 inhibitors have yet been approved for clinical use, especially in treating liver diseases. Identifying selective and efficacious AP-1 inhibitors serves as a viable therapeutic strategy for liver diseases.

Aberrant expression of IL-17, IL-20, IL-22, and IL-33 is found in chronic liver disease, but the interaction between the inflammatory mediators and c-Myc must accumulate. Our review will help to understand the links between hepatic inflammation mediators and c-Myc in CLDs.

\section{Abbreviations}

ALD: Alcoholic liver disease

CCA: Cholangiocarcinoma

CLDs: Chronic liver diseases

ECs: Endothelial cells

HBV: Hepatitis B virus

HCC: Hepatocellular carcinoma

HCV: Hepatitis $\mathrm{C}$ virus

HSCs: Hepatic stellate cells

IFN: Interferon

IL: $\quad$ Interleukin

IL-1R: Interleukin-1 receptor

IL-1Ra: Interleukin-1 receptor antagonist

JNK: $\quad$ c-Jun N-terminal kinase

LPS: Lipopolysaccharide

MDP: Muramyl dipeptide

MSCs: Mesenchymal stem cells

NASH: Nonalcoholic steatohepatitis

NK: $\quad$ Natural killer

NLR: NOD-like receptor

NF- $\kappa$ B: Nuclear factor $\kappa \mathrm{B}$

PI3K: Phosphatidylinositol 3-kinase

PPAR $\gamma$ : Peroxisome proliferator-activated receptor gamma

STAT: $\quad$ Signal transducers and activators of transcription

SykPTK: Spleen tyrosine kinase and protein tyrosine kinase
TLR: Toll-like receptor

TNF- $\alpha$ : Tumor necrosis factor $\alpha$

VEGF: Vascular endothelial growth factor.

\section{Conflict of Interests}

No competing financial interests exist for any of the authors.

\section{Acknowledgments}

This work was supported by NIH Grants R01DK092407 (to SC Lu and H. Yang) and R01CA172086 (to SC Lu, H. Yang, ML Martínez-Chantar, and JM Mato) and the National Natural Science Foundation of China (no. 81272735, to Ting Liu). The authors cannot express enough thanks to Yaqi Chen for data collection. They offer their sincere appreciation for the review critical reading from Stephanie Maldonado and support from Dr. Shelly Lu.

\section{References}

[1] H. Yang, T. W. H. Li, J. Peng et al., "A mouse model of cholestasis-associated cholangiocarcinoma and transcription factors involved in progression," Gastroenterology, vol. 141, no. 1, pp. 378-388, 2011.

[2] H. Yang, T. W. H. Li, K. S. Ko, M. Xia, and S. C. Lu, “'Switch from Mnt-Max to Myc-Max induces p53 and cyclin D1 expression and apoptosis during cholestasis in mouse and human hepatocytes," Hepatology, vol. 49, no. 3, pp. 860-870, 2009.

[3] C. Grandori, S. M. Cowley, L. P. James, and R. N. Eisenman, "The Myc/Max/Mad network and the transcriptional control of cell behavior," Annual Review of Cell and Developmental Biology, vol. 16, no. 1, pp. 653-699, 2000.

[4] T. Wahlstrom and M. A. Henriksson, "Impact of MYC in regulation of tumor cell metabolism," Biochimica et Biophysica Acta, 2014.

[5] J. M. Link and P. J. Hurlin, "The activities of MYC, MNT and the MAX-interactome in lymphocyte proliferation and oncogenesis," Biochimica et Biophysica Acta-Gene Regulatory Mechanisms, 2014.

[6] E. Voronov, Y. Carmi, and R. N. Apte, "The role IL-1 in tumormediated angiogenesis," Frontiers in Physiology, no. 114, Article ID Article 114, pp. 1-8, 2014.

[7] E. Voronov, S. Dotan, Y. Krelin et al., "Unique versus redundant functions of IL- $1 \alpha$ and IL- $1 \beta$ in the tumor microenvironment," Frontiers in Immunology, vol. 4, article 177, 2013.

[8] G. Szabo and T. Csak, "Inflammasomes in liver diseases," Journal of Hepatology, vol. 57, no. 3, pp. 642-654, 2012.

[9] W. Z. Mehal, "The inflammasome in liver injury and nonalcoholic fatty liver disease," Digestive Diseases, vol. 32, no. 5, pp. 507-515, 2014.

[10] K. Miura, Y. Kodama, S. Inokuchi et al., "Tolllike receptor 9 promotes steatohepatitis by induction of interleukin-1beta in mice," Gastroenterology, vol. 139, no. 1, pp. 323-334, 2010.

[11] R. G. Gieling, K. Wallace, and Y.-P. Han, "Interleukin-1 participates in the progression from liver injury to fibrosis," The American Journal of Physiology: Gastrointestinal and Liver Physiology, vol. 296, no. 6, pp. G1324-G1331, 2009.

[12] J. Petrasek, S. Bala, T. Csak et al., "IL-1 receptor antagonist ameliorates inflammasome-dependent alcoholic steatohepatitis 
in mice," The Journal of Clinical Investigation, vol. 122, no. 10, pp. 3476-3489, 2012.

[13] J. P. Pradere, J. Kluwe, S. de Minicis et al., "Hepatic macrophages but not dendritic cells contribute to liver fibrosis by promoting the survival of activated hepatic stellate cells in mice," Hepatology, vol. 58, no. 4, pp. 1461-1473, 2013.

[14] A. Wree, A. Eguchi, M. D. Mcgeough et al., "NLRP3 inflammasome activation results in hepatocyte pyroptosis, liver inflammation, and fibrosis in mice," Hepatology, vol. 59, no. 3, pp. 898910, 2014.

[15] M. G. Borrello, D. Degl'Innocenti, and M. A. Pierotti, "Inflammation and cancer: the oncogene-driven connection," Cancer Letters, vol. 267, no. 2, pp. 262-270, 2008.

[16] K. Shchors, E. Shchors, F. Rostker, E. R. Lawlor, L. BrownSwigart, and G. I. Evan, "The Myc-dependent angiogenic switch in tumors is mediated by interleukin $1 \beta$," Genes and Development, vol. 20, no. 18, pp. 2527-2538, 2006.

[17] E. Voronov, D. S. Shouval, Y. Krelin et al., "IL-1 is required for tumor invasiveness and angiogenesis," Proceedings of the National Academy of Sciences of the United States of America, vol. 100, no. 5, pp. 2645-2650, 2003.

[18] R. N. Apte and E. Voronov, "Is interleukin-1 a good or bad "guy" in tumor immunobiology and immunotherapy?" Immunological Reviews, vol. 222, no. 1, pp. 222-241, 2008.

[19] J. Kang, P. G. Rychahou, T. A. Ishola, J. M. Mourot, B. M. Evers, and D. H. Chung, "N-Myc is a novel regulator of PI3K-mediated VEGF expression in neuroblastoma," Oncogene, vol. 27, no. 28, pp. 3999-4007, 2008.

[20] T. A. Baudino, C. McKay, H. Pendeville-Samain et al., "c$\mathrm{Myc}$ is essential for vasculogenesis and angiogenesis during development and tumor progression," Genes and Development, vol. 16, no. 19, pp. 2530-2543, 2002.

[21] M. A. Burchill, J. Yang, K. B. Vang, and M. A. Farrar, "Interleukin-2 receptor signaling in regulatory $\mathrm{T}$ cell development and homeostasis," Immunology Letters, vol. 114, no. 1, pp. 1-8, 2007.

[22] M. C. Mingari, F. Gerosa, G. Carra et al., "Human interleukin-2 promotes proliferation of activated B cells via surface receptors similar to those of activated T cells," Nature, vol. 312, no. 5995, pp. 641-643, 1984.

[23] M. Lenardo, F. K.-M. Chan, F. Hornung et al., "Mature $\mathrm{T}$ lymphocyte apoptosis-immune regulation in a dynamic and unpredictable antigenic environment," Annual Review of Immunology, vol. 17, pp. 221-253, 1999.

[24] J. Sikora, G. Dworacki, M. Trybus, H. Batura-Gabryel, and J. Zeromski, "Correlation between DNA content, expression of Ki-67 antigen of tumor cells and immunophenotype of lymphocytes from malignant pleural effusions," Tumor Biology, vol. 19, no. 3, pp. 196-204, 1998.

[25] T. Senba, M. Kurki, F. Arakawa et al., "Tumor growth suppression by a mouse/human ahimteric anti-CEA antibody and lymphokine-activated killer cells in vitro and in SCID mouse xenograft model," Anticancer Research, vol. 1A, no. 18, pp. 17-24, 1998.

[26] Y. Minami, Y. Nakagawa, A. Kawahara et al., "Protein tyrosine kinase Syk is associated with and activated by the IL-2 receptor: possible link with the c-myc induction pathway," Immunity, vol. 2, no. 1, pp. 89-100, 1995.

[27] T. Miyazaki, Z. J. Liu, A. Kawahara et al., "Three distinct IL-2 signaling pathways mediated by bcl-2, c-myc, and lck cooperate in hematopoietic cell proliferation," Cell, vol. 81, no. 2, pp. 223231, 1995.
[28] A.-B. Stittrich, C. Haftmann, E. Sgouroudis et al., "The microRNA miR-182 is induced by IL- 2 and promotes clonal expansion of activated helper T lymphocytes," Nature Immunology, vol. 11, no. 11, pp. 1057-1062, 2010.

[29] M. Tinel, J. Elkahwaji, M. A. Robin et al., "Interleukin-2 overexpresses c-myc and down-regulates cytochrome P-450 in rat hepatocytes," Journal of Pharmacology and Experimental Therapeutics, vol. 289, no. 2, pp. 649-655, 1999.

[30] M. M. Fung, Y.-L. Chu, J. L. Fink, A. Wallace, and K. L. McGuire, "IL-2- and STAT5-regulated cytokine gene expression in cells expressing the Tax protein of HTLV-1," Oncogene, vol. 24, no. 29, pp. 4624-4633, 2005.

[31] M. G. Neuman, J.-P. Benhamou, P. Marcellin et al., "Cytokinechemokine and apoptotic signatures in patients with hepatitis C," Translational Research, vol. 149, no. 3, pp. 126-136, 2007.

[32] K. Nelms, A. D. Keegan, J. Zamorano, J. J. Ryan, and W. E. Paul, "The IL-4 receptor: signaling mechanisms and biologic functions," Annual Review of Immunology, vol. 17, pp. 701-738, 1999.

[33] I. G. Luzina, A. D. Keegan, N. M. Heller, G. A. W. Rook, T. Shea-Donohue, and S. P. Atamas, "Regulation of inflammation by interleukin-4: a review of "alternatives'”, Journal of Leukocyte Biology, vol. 92, no. 4, pp. 753-764, 2012.

[34] S. H. Cho, A. K. Ahn, P. Bhargava et al., "Glycolytic rate and lymphomagenesis depend on PARP14, an ADP ribosyltransferase of the B aggressive lymphoma (BAL) family," Proceedings of the National Academy of Sciences of the United States of America, vol. 108, no. 38, pp. 15972-15977, 2011.

[35] L. Soon, L. Flechner, J. S. Gutkind et al., "Insulin-like growth factor I synergizes with interleukin 4 for hematopoietic cell proliferation independent of insulin receptor substrate expression," Molecular and Cellular Biology, vol. 19, no. 5, pp. 3816-3828, 1999.

[36] T. Sato, X. Liu, H. Basma et al., "IL-4 induces differentiation of human embryonic stem cells into fibrogenic fibroblast-like cells," Journal of Allergy and Clinical Immunology, vol. 127, no. 6, pp. 1595.e9-1603.e9, 2011.

[37] M. Brock, M. Trenkmann, R. E. Gay, S. Gay, R. Speich, and L. C. Huber, "MicroRNA-18a enhances the interleukin-6-mediated production of the acute-phase proteins fibrinogen and haptoglobin in human hepatocytes," The Journal of Biological Chemistry, vol. 286, no. 46, pp. 40142-40150, 2011.

[38] M. Trauner, P. Fickert, and R. E. Stauber, "Inflammationinduced cholestasis," Journal of Gastroenterology and Hepatology (Australia), vol. 14, no. 10, pp. 946-959, 1999.

[39] A. Picardi, U. V. Gentilucci, E. M. Zardi, D. D’Avola, A. Amoroso, and A. Afeltra, "The role of ribavirin in the combination therapy of hepatitis C virus infection," Current Pharmaceutical Design, vol. 10, no. 17, pp. 2081-2092, 2004.

[40] K. Xiang-Min, L. I. Da-Guang, C. Bo et al., "Alcoholic liver disease serum TGF-IL-6 and IL-8 levels and its clinical significance," Chinese Journal of Laboratory Diagnosis, vol. 17, no. 7, pp. 1233-1234, 2013.

[41] H. Wehbe, R. Henson, F. Meng, J. Mize-Berge, and T. Patel, "Interleukin-6 contributes to growth in cholangiocarcinoma cells by aberrant promoter methylation and gene expression," Cancer Research, vol. 66, no. 21, pp. 10517-10524, 2006.

[42] Y. Shi, P. Frost, B. Hoang, A. Benavides, J. Gera, and A. Lichtenstein, "IL-6-induced enhancement of c-Myc translation in multiple myeloma cells: critical role of cytoplasmic localization of the RNA-binding protein hnRNP A1," The Journal of Biological Chemistry, vol. 286, no. 1, pp. 67-78, 2011. 
[43] K. Shamsasenjan, K.-I. Otsuyama, S. Abroun et al., "IL-6induced activation of MYC is responsible for the downregulation of CD33 expression in CD33(+) myeloma cells," International Journal of Hematology, vol. 89, no. 3, pp. 310-318, 2009.

[44] T. Ezure, T. Sakamoto, H. Tsuji et al., "The development and compensation of biliary cirrhosis in interleukin-6-deficient mice," The American Journal of Pathology, vol. 156, no. 5, pp. 1627-1639, 2000.

[45] H. Wang, F. Lafdil, X. Kong, and B. Gao, "Signal transducer and activator of transcription 3 in liver diseases: a novel therapeutic target," International Journal of Biological Sciences, vol. 7, no. 5, pp. 536-550, 2011.

[46] J. Park, L. Tadlock, G. J. Gores, and T. Patel, "Inhibition of interleukin 6-mediated mitogen-activated protein kinase activation attenuates growth of a cholangiocarcinoma cell line," Hepatology, vol. 30, no. 5, pp. 1128-1133, 1999.

[47] J. M. Saito and J. J. Maher, "Bile duct ligation in rats induces biliary expression of cytokine- induced neutrophil chemoattractant," Gastroenterology, vol. 118, no. 6, pp. 1157-1168, 2000.

[48] G. Syal, M. Fausther, and J. A. Dranoff, "Advances in cholangiocyte immunobiology," The American Journal of Physiology: Gastrointestinal and Liver Physiology, vol. 303, no. 10, pp. G1077G1086, 2012.

[49] E. Seki and R. F. Schwabe, "Hepatic inflammation and fibrosis: functional links and key pathways," Hepatology, 2014.

[50] K. Bessho, R. Mourya, P. Shivakumar et al., "Gene expression signature for biliary atresia and a role for interleukin- 8 in pathogenesis of experimental disease," Hepatology, vol. 60, no. 1, pp. 211-223, 2014.

[51] R. S. Yahya, O. H. Ghanem, A. A. A. Foyouh, M. A. Atwa, and S. A. Enany, "Role of interleukin-8 and oxidative stress in patients with hepatocellular carcinoma," Clinical Laboratory, vol. 59, no. 9-10, pp. 969-976, 2013.

[52] H. W. Zimmermann, S. Seidler, N. Gassler et al., "Interleukin-8 is activated in patients with chronic liver diseases and associated with hepatic macrophage accumulation in human liver fibrosis," PLoS ONE, vol. 6, no. 6, Article ID e21381, 2011.

[53] K. S. Ko, J. Peng, and H. Yang, "Animalmodels of cholangiocarcinoma," Current Opinion in Gastroenterology, vol. 29, no. 3, pp. 312-318, 2013.

[54] K. Ninlawan, S. P. O’Hara, P. L. Splinter et al., "Opisthorchis viverrini excretory/secretory products induce toll-like receptor 4 upregulation and production of interleukin 6 and 8 in cholangiocyte," Parasitology International, vol. 59, no. 4, pp. 616-621, 2010.

[55] R. Gonzalez-Amaro, C. Garcia-Monzon, L. Garcia-Buey et al., "Induction of tumor necrosis factor $\alpha$ production by human hepatocytes in chronic viral hepatitis," The Journal of Experimental Medicine, vol. 179, no. 3, pp. 841-848, 1994.

[56] M. Fujimoto, M. Uemura, Y. Nakatani et al., "Plasma endotoxin and serum cytokine levels in patients with alcoholic hepatitis: relation to severity of liver disturbance," Alcoholism: Clinical and Experimental Research, vol. 24, no. 4, supplement, pp. 48s-54s, 2000.

[57] J. D. Gordan, J. A. Bertout, C.-J. Hu, J. A. Diehl, and M. C. Simon, "HIF-2alpha promotes hypoxic cell proliferation by enhancing c-myc transcriptional activity," Cancer Cell, vol. 11, no. 4, pp. 335-347, 2007.

[58] U. Florczyk, S. Czauderna, A. Stachurska et al., "Opposite effects of HIF- $1 \alpha$ and HIF- $2 \alpha$ on the regulation of IL- 8 expression in endothelial cells," Free Radical Biology and Medicine, vol. 51, no. 10, pp. 1882-1892, 2011.

[59] A. Loboda, A. Stachurska, U. Florczyk et al., "HIF-1 induction attenuates Nrf2-dependent IL-8 expression in human endothelial cells," Antioxidants \& Redox Signaling, vol. 11, no. 7, pp. 15011517, 2009.

[60] K. H. Yoo, Y. H. Sung, M. H. Yang et al., "Inactivation of Mxil induces Il-8 secretion activation in polycystic kidney," Biochemical and Biophysical Research Communications, vol. 356, no. 1, pp. 85-90, 2007.

[61] H. Zhang, P. Gao, R. Fukuda et al., "HIF-1 inhibits mitochondrial biogenesis and cellular respiration in VHL-deficient renal cell carcinoma by repression of C-MYC activity," Cancer Cell, vol. 11, no. 5, pp. 407-420, 2007.

[62] M. Dominguez, R. Miquel, J. Colmenero et al., "Hepatic expression of CXC chemokines predicts portal hypertension and survival in patients with alcoholic hepatitis," Gastroenterology, vol. 136, no. 5, pp. 1639-1650, 2009.

[63] A. de la Coste, A. Mignon, M. Fabre et al., "Paradoxical inhibition of c-myc-induced carcinogenesis by Bcl-2 in transgenic mice," Cancer Research, vol. 59, no. 19, pp. 5017-5022, 1999.

[64] P. J. Murray, "Understanding and exploiting the endogenous interleukin-10/STAT3-mediated anti-inflammatory response," Current Opinion in Pharmacology, vol. 6, no. 4, pp. 379-386, 2006.

[65] D. Yu, M. Dews, A. Park, J. W. Tobias, and A. Thomas-Tikhonenko, "Inactivation of Myc in murine two-hit B lymphomas causes dormancy with elevated levels of interleukin 10 receptor and CD20: implications for adjuvant therapies," Cancer Research, vol. 65, no. 12, pp. 5454-5461, 2005.

[66] F. Robert, J. R. Mills, A. Agenor et al., "Targeting protein synthesis in a Myc/mTOR-driven model of anorexia-cachexia syndrome delays its onset and prolongs survival," Cancer Research, vol. 72, no. 3, pp. 747-756, 2012.

[67] P. Rai, A. Plagov, X. Lan et al., "mTOR plays a critical role in p53induced oxidative kidney cell injury in HIVAN," The American Journal of Physiology: Renal Physiology, vol. 305, no. 3, pp. F343F354, 2013.

[68] Z. Lai, S. Kalkunte, and S. Sharma, "A critical role of interleukin10 in modulating hypoxia-induced preeclampsia-like disease in mice," Hypertension, vol. 57, no. 3, pp. 505-514, 2011.

[69] J. A. Fielhaber, Y.-S. Han, J. Tan et al., "Inactivation of mammalian target of rapamycin increases STAT1 nuclear content and transcriptional activity in $\alpha 4$ - and protein phosphatase $2 \mathrm{~A}$ dependent fashion," The Journal of Biological Chemistry, vol. 284, no. 36, pp. 24341-24353, 2009.

[70] L. Wang, Y. Zhao, Y. Liu et al., "IFN- $\gamma$ and TNF- $\alpha$ synergistically induce mesenchymal stem cell impairment and tumorigenesis via $\mathrm{NF} \kappa \mathrm{B}$ signaling," Stem Cells, vol. 31, no. 7, pp. 1383-1395, 2013.

[71] V. K. W. Wong, M. M. Zhang, H. Zhou et al., "Saikosaponin$\mathrm{d}$ enhances the anticancer potency of TNF- $\alpha$ via overcoming its undesirable response of activating NF-kappa B signalling in cancer cells," Evidence-Based Complementary and Alternative Medicine, vol. 2013, Article ID 745295, 14 pages, 2013.

[72] A. Fernandez, M. C. Marin, T. McDonnell, and H. N. Ananthaswamy, "Differential sensitivity of normal and Ha-rastransformed $\mathrm{C} 3 \mathrm{H}$ mouse embryo fibroblasts to tumor necrosis factor: induction of bcl-2, c-myc, and manganese superoxide dismutase in resistant cells," Oncogene, vol. 9, no. 7, pp. 20092017, 1994. 
[73] A. Tobler, D. Johnston, and H. P. Koeffler, "Recombinant human tumor necrosis factor $(\alpha)$ regulates c-myc expression in HL-60 cells at the level of transcription," Blood, vol. 70, no. 1, pp. 200205, 1987.

[74] S. Dooley and P. Ten Dijke, "TGF- $\beta$ in progression of liver disease," Cell and Tissue Research, vol. 347, no. 1, pp. 245-256, 2012.

[75] G. Turcatel, N. Rubin, A. El-Hashash, and D. Warburton, "Mir-99a and mir-99b modulate TGF- $\beta$ induced epithelial to mesenchymal plasticity in normal murine mammary gland cells," PLoS ONE, vol. 7, no. 1, Article ID e31032, 2012.

[76] L. Maggio-Price, P. Treuting, H. Bielefeldt-Ohmann et al., "Bacterial infection of Smad3/Rag2 double-null mice with transforming growth factor- $\beta$ dysregulation as a model for studying inflammation-associated colon cancer," The American Journal of Pathology, vol. 174, no. 1, pp. 317-329, 2009.

[77] K. Yoshida and K. Matsuzaki, "Differential regulation of TGF$\beta /$ Smad signaling in hepatic stellate cells between acute and chronic liver injuries," Frontiers in Physiology, vol. 3, article 53, 2012.

[78] R. J. Grumont, A. Strasser, and S. Gerondakis, "B Cell growth is controlled by phosphatidylinosotol 3-kinase-dependent induction of Rel/NF- $\kappa \mathrm{B}$ regulated c-myc transcription," Molecular Cell, vol. 10, no. 6, pp. 1283-1294, 2002.

[79] F. Siebelt, I. Berberich, G. Shu, E. Serfling, and E. A. Clark, "Role for CD40-mediated activation of c-Rel and maintenance of cmyc RNA levels in mitigating anti-IgM-induced growth arrest," Cellular Immunology, vol. 181, no. 1, pp. 13-22, 1997.

[80] Z. Wang, J. P. Xu, Y. C. Zheng et al., "Peroxisome proliferatoractivated receptor gamma inhibits hepatic fibrosis in rats," Hepatobiliary and Pancreatic Diseases International, vol. 10, no. 1, pp. 64-71, 2011.

[81] B. Shen, E. S. H. Chu, G. Zhao et al., "PPARgamma inhibits hepatocellular carcinoma metastases in vitro and in mice," British Journal of Cancer, vol. 106, no. 9, pp. 1486-1494, 2012.

[82] K. Matsusue, M. Haluzik, G. Lambert et al., "Liver-specific disruption of PPAR $\gamma$ in leptin-deficient mice improves fatty liver but aggravates diabetic phenotypes," Journal of Clinical Investigation, vol. 111, no. 5, pp. 737-747, 2003.

[83] B. Zarnegar, J. Q. He, G. Oganesyan, A. Hoffmann, D. Baltimore, and G. Cheng, "Unique CD40-mediated biological program in $\mathrm{B}$ cell activation requires both type 1 and type 2 NF- $\kappa \mathrm{B}$ activation pathways," Proceedings of the National Academy of Sciences of the United States of America, vol. 101, no. 21, pp. 8108$8113,2004$.

[84] J. J. Schlezinger, B. A. Jensen, K. K. Mann, H. Y. Ryu, and D. H. Sherr, "Peroxisome proliferator-activated receptor $\gamma$-mediated NF-kappaB activation and apoptosis in pre-B cells," Journal of Immunology, vol. 169, no. 12, pp. 6831-6841, 2002.

[85] Z. You, L. V. Madrid, D. Saims, J. Sedivy, and C.-Y. Wang, "c-Myc sensitizes cells to tumor necrosis factor-mediated apoptosis by inhibiting nuclear factor $\kappa \mathrm{B}$ transactivation," Journal of Biological Chemistry, vol. 277, no. 39, pp. 36671-36677, 2002.

[86] F. A. L. A. Rosa, J. W. Pierce, and G. E. Sonenshein, “Differential regulation of the c-myc oncogene promoter by the NF- $\kappa \mathrm{B}$ Rel family of transcription factors," Molecular and Cellular Biology, vol. 14, no. 2, pp. 1039-1044, 1994.

[87] R. Visconti, J. Cerutti, S. Battista et al., "Expression of the neoplastic phenotype by human thyroid carcinoma cell lines requires NF $\kappa \mathrm{B}$ p65 protein expression," Oncogene, vol. 15, no. 16, pp. 1987-1994, 1997.
[88] D. W. Kim, L. Gazourian, S. A. Quadri, D. H. Sherr, and G. E. Sonenshein, "The RelA NF- $\kappa$ B subunit and the aryl hydrocarbon receptor (AhR) cooperate to transactivate the cmyc promoter in mammary cells," Oncogene, vol. 19, no. 48, pp. 5498-5506, 2000.

[89] S. Beer, A. Zetterberg, R. A. Ihrie et al., "Developmental context determines latency of MYC-induced tumorigenesis," PLoS Biology, vol. 2, no. 11, pp. 1785-1798, 2004.

[90] L. Amicone, O. Terradillos, L. Calvo et al., "Synergy between truncated c-Met (cyto-Met) and c-Myc in liver oncogenesis: importance of TGF- $\beta$ signalling in the control of liver homeostasis and transformation," Oncogene, vol. 21, no. 9, pp. 1335$1345,2002$.

[91] S. Kim, Q. Li, C. V. Dang, and L. A. Lee, "Induction of ribosomal genes and hepatocyte hypertrophy by adenovirusmediated expression of c-Myc in vivo," Proceedings of the National Academy of Sciences of the United States of America, vol. 97, no. 21, pp. 11198-11202, 2000.

[92] E. Baena, A. Gandarillas, M. Vallespinós et al., "c-Myc regulates cell size and ploidy but is not essential for postnatal proliferation in liver," Proceedings of the National Academy of Sciences of the United States of America, vol. 102, no. 20, pp. 7286-7291, 2005.

[93] H. P. Glauert, A. Eyigor, J. C. Tharappel, S. Cooper, E. Y. Lee, and B. T. Spear, "Inhibition of hepatocarcinogenesis by the deletion of the $\mathrm{p} 50$ subunit of NF- $\kappa \mathrm{B}$ in mice administered the peroxisome proliferator Wy-14,643," Toxicological Sciences, vol. 90, no. 2, pp. 331-336, 2006.

[94] H. Ishikawa, E. Claudio, D. Dambach, C. Raventós-Suárez, C. Ryan, and R. Bravo, "Chronic inflammation and susceptibility to bacterial infections in mice lacking the polypeptide (p)105 precursor (NF- $\kappa \mathrm{B} 1$ ) but expressing p50," The Journal of Experimental Medicine, vol. 187, no. 7, pp. 985-996, 1998.

[95] T. Bosschaerts, Y. Morias, B. Stijlemans et al., "IL-10 limits production of pathogenic TNF by M1 myeloid cells through induction of nuclear NF- $\kappa$ B p50 member in Trypanosoma congolense infection-resistant C57BL/6 mice," European Journal of Immunology, vol. 41, no. 11, pp. 3270-3280, 2011.

[96] N. R. Chapman, G. A. Webster, P. J. Gillespie, B. J. Wilson, D. H. Crouch, and N. D. Perkins, "A novel form of the RelA nuclear factor $\kappa \mathrm{B}$ subunit is induced by and forms a complex with the proto-oncogene c-Myc," Biochemical Journal, vol. 366, no. 2, pp. 459-469, 2002.

[97] J. Klefstrom, E. Arighi, T. Littlewood et al., "Induction of TNF-sensitive cellular phenotype by c-Myc involves p53 and impaired NF- $\kappa$ B activation," The EMBO Journal, vol. 16, no. 24, pp. 7382-7392, 1997.

[98] J. Klefstrom, I. Västrik, E. Saksela, J. Valle, M. Eilers, and K. Alitalo, "c-Myc induces cellular susceptibility to the cytotoxic action of TNF- $\alpha$," The EMBO Journal, vol. 13, no. 22, pp. 5442 $5450,1994$.

[99] T. Hsu, T. Moroy, J. Etiemble et al., "Activation of c-myc by woodchuck hepatitis virus insertion in hepatocellular carcinoma," Cell, vol. 55, no. 4, pp. 627-635, 1988.

[100] C. Transy, G. Fourel, W. S. Robinson, P. Tiollais, P. L. Marion, and M.-A. Buendia, "Frequent amplification of c-myc in ground squirrel liver tumors associated with past or ongoing infection with a hepadnavirus," Proceedings of the National Academy of Sciences of the United States of America, vol. 89, no. 9, pp. 38743878, 1992.

[101] H. Yang, T. W. H. Li, Y. Zhou et al., "Activation of a novel c-MycmiR27-Prohibitin 1 circuitry in cholestatic liver injury inhibits 
GSH synthesis in mice," Antioxidants \& Redox Signaling, vol. 22, no. 3, pp. 259-274, 2015.

[102] K.-L. Chan, X.-Y. Guan, and I. O.-L. Ng, "High-throughput tissue microarray analysis of c-myc activation in chronic liver diseases and hepatocellular carcinoma," Human Pathology, vol. 35, no. 11, pp. 1324-1331, 2004.

[103] M. Asim, R. Chaturvedi, S. Hoge et al., "Helicobacter pylori induces ERK-dependent formation of a phospho-c-Fos.cJun activator protein-1 complex that causes apoptosis in macrophages," The Journal of Biological Chemistry, vol. 285, no. 26, pp. 20343-20357, 2010.

[104] L. Min, Y. Ji, L. Bakiri et al., "Liver cancer initiation is controlled by AP-1 through SIRT6-dependent inhibition of survivin," Nature Cell Biology, vol. 14, no. 11, pp. 1203-1211, 2012.

[105] N. Kalra and V. Kumar, "c-Fos is a mediator of the c-Mycinduced apoptotic signaling in serum-deprived hepatoma cells via the p38 mitogen-activated protein kinase pathway," The Journal of Biological Chemistry, vol. 279, no. 24, pp. 25313-25319, 2004.

[106] A. Behrens, M. Sibilia, J.-P. David et al., "Impaired postnatal hepatocyte proliferation and liver regeneration in mice lacking c-jun in the liver," EMBO Journal, vol. 21, no. 7, pp. 1782-1790, 2002.

[107] E. Stepniak, R. Ricci, R. Eferl et al., "c-Jun/AP-1 controls liver regeneration by repressing p53/p21 and p38 MAPK activity," Genes and Development, vol. 20, no. 16, pp. 2306-2314, 2006.

[108] L. Hui, K. Zatloukal, H. Scheuch, E. Stepniak, and E. F. Wagner, "Proliferation of human HCC cells and chemically induced mouse liver cancers requires JNK1-dependent p21 downregulation," The Journal of Clinical Investigation, vol. 118, no. 12, pp. 3943-3953, 2008.

[109] T. Sakurai, S. Maeda, L. Chang, and M. Karin, "Loss of hepatic NF- $\kappa$ B activity enhances chemical hepatocarcinogenesis through sustained c-Jun N-terminal kinase 1 activation," Proceedings of the National Academy of Sciences of the United States of America, vol. 103, no. 28, pp. 10544-10551, 2006.

[110] J. Pihlajamäki, T. Kuulasmaa, D. Kaminska et al., "Serum interleukin 1 receptor antagonist as an independent marker of non-alcoholic steatohepatitis in humans," Journal of Hepatology, vol. 56, no. 3, pp. 663-670, 2012.

[111] S. Seidler, H. W. Zimmermann, R. Weiskirchen, C. Trautwein, and F. Tacke, "Elevated circulating soluble interleukin-2 receptor in patients with chronic liver diseases is associated with nonclassical monocytes," BMC Gastroenterology, vol. 12, article 38, 2012.

[112] R. Bahirwani and K. R. Reddy, "Drug-induced liver injury due to cancer chemotherapeutic agents," Seminars in Liver Disease, vol. 34, no. 2, pp. 162-171, 2014.

[113] B. Gao, "Hepatoprotective and anti-inflammatory cytokines in alcoholic liver disease," Journal of Gastroenterology and Hepatology, vol. 27, no. 2, pp. 89-93, 2012.

[114] M. Bonacini, M. Ghabril, and H. L. Bonkovsky, "Hepatotoxicity of anti-TNF agents," Digestive Diseases and Sciences, vol. 59, no. 5, pp. 1070-1071, 2014.

[115] S. Dooley and P. T. Dijke, "TGF- $\beta$ in progression of liver disease," Cell and Tissue Research, vol. 347, no. 1, pp. 245-256, 2012.

[116] P. Liu, E. Kimmoun, A. Legrand et al., "Activation of NFkappaB, AP-1 and STAT transcription factors is a frequent and early event in human hepatocellular carcinomas," Journal of Hepatology, vol. 37, no. 1, pp. 63-71, 2002.
[117] C. Dorn, J. C. Engelmann, M. Saugspier et al., "Increased expression of c-Jun in nonalcoholic fatty liver disease," Laboratory Investigation, vol. 94, no. 4, pp. 394-408, 2014.

[118] S. C. Hasenfuss, L. Bakiri, M. K. Thomsen, E. G. Williams, J. Auwerx, and E. F. Wagner, "Regulation of steatohepatitis and PPAR $\gamma$ signaling by distinct AP-1 dimers," Cell Metabolism, vol. 19, no. 1, pp. 84-95, 2014.

[119] Y. Liu, C. Lu, Q. Shen, D. Munoz-Medellin, H. Kim, and P. H. Brown, "AP-1 blockade in breast cancer cells causes cell cycle arrest by suppressing G1 cyclin expression and reducing cyclindependent kinase activity," Oncogene, vol. 23, no. 50, pp. 82388246, 2004.

[120] Y. Tachibana, Y. Nakamoto, N. Mukaida, and S. Kaneko, "Intrahepatic interleukin-8 production during disease progression of chronic hepatitis C," Cancer Letters, vol. 251, no. 1, pp. 36-42, 2007.

[121] J.-F. A. Tsai, J.-E. Jeng, L.-Y. Chuang, W.-Y. U. Chang, and J.-H. Tsai, "Urinary transforming growth factor $\beta_{1}$ levels in hepatitis $c$ virus-related chronic liver disease: correlation between high levels and severity of disease," Hepatology, vol. 25, no. 5, pp. 11411146, 1997.

[122] M. A. Ali, B. A. Koura, N. el-Mashad, and M. H. E. Zaghloul, "The Bcl-2 and TGF-betal levels in patients with chronic hepatitis $\mathrm{C}$, liver cirrhosis and hepatocellular carcinoma," The Egyptian Journal of Immunology, vol. 11, no. 1, pp. 83-90, 2004.

[123] M. Reiser, C. G. Marousis, D. R. Nelson et al., "Serum interleukin 4 and interleukin 10 levels in patients with chronic hepatitis C virus infection," Journal of Hepatology, vol. 26, no. 3, pp. 471-478, 1997.

[124] D. Xiaoyan, C. Jun, and D. Hong, "Hepatitis b and hepatitis c virus (HCV) for the c-jun gene of regulation," World Journal of Gastroenterology, vol. 12, no. 4, pp. 935-937, 2004.

[125] F. Giammarco, "Molecular mechanisms of cholangiocarcinoma," World Journal of Gastrointestinal Pathophysiology, vol. 1, no. 1, pp. 12-22, 2010.

[126] L. L. Giong, L. Jia, and K. Zengji, "Cytokines and alcoholic liver disease," Chinese Bulletin of Life Sciences, vol. 22, no. 12, pp. 12411246, 2010.

[127] F. T. Crews, R. Bechara, L. A. Brown et al., "Cytokines and alcohol," Alcoholism: Clinical and Experimental Research, vol. 30, no. 4, pp. 720-730, 2006.

[128] J. Akiba, H. Yano, and S. Ogasawara, "Expression and function of interleukin-8 in human hepatocellular carcinoma," International Journal of Oncology, vol. 18, no. 2, pp. 257-264, 2001.

[129] P. Liu, J. F. Flejou, G. Feldmann, and D. Bernuau, "Activation of ras oncogene in livers with cirrhosis," Journal of Hepatology, vol. 21, no. 6, pp. 1103-1108, 1994.

[130] M. S. Hayden, A. P. West, and S. Ghosh, "NF- $\kappa$ B and the immune response," Oncogene, vol. 25, no. 51, pp. 6758-6780, 2006.

[131] M. M. Kemeny, G. I. Botchkina, M. Ochani, M. Bianchi, C. Urmacher, and K. J. Tracey, "The tetravalent guanylhydrazone CNI-1493 blocks the toxic effects of interleukin-2 without diminishing antitumor efficacy," Proceedings of the National Academy of Sciences of the United States of America, vol. 95, no. 8, pp. 4561-4566, 1998.

[132] L. C. Miller, A. Sharma, A. F. McKusick, J. P. Tassoni, C. A. Dinarello, and M. M. Kaplan, "Synthesis of interleukin-1 $\beta$ in primary biliary cirrhosis: relationship to treatment with methotrexate or colchicine and disease progression," Hepatology, vol. 22, no. 2, pp. 518-524, 1995. 
[133] K. Wakabayashi, Z. X. Lian, Y. Moritoki et al., "IL-2 receptor $\alpha^{-/-}$mice and the development of primary biliary cirrhosis," Hepatology, vol. 44, no. 5, pp. 1240-1249, 2006.

[134] C. Homann, T. L. Benfield, N. Albertgrauda, and P. Garred, "Neopterin and interleukin-8-prognosis in alcohol-induced cirrhosis," Liver International, vol. 20, no. 6, pp. 442-449, 2000.

[135] S. Kitaoka, G. Shiota, and H. Kawasaki, "Serum levels of interleukin-10, interleukin-12 and soluble interleukin-2 receptor in chronic liver disease type C," Hepato-Gastroenterology, vol. 50, no. 53, pp. 1569-1574, 2003.

[136] Y. Ding, L. Zhao, H. Mei, Z.-H. Huang, and S.-L. Zhang, "Alterations of biliary biochemical constituents and cytokines in infantile hepatitis syndrome," World Journal of Gastroenterology, vol. 12, no. 43, pp. 7038-7041, 2006.

[137] K. Kovalovich, W. Li, R. DeAngelis, L. E. Greenbaum, G. Ciliberto, and R. Taub, "Interleukin-6 protects against Fas-mediated death by establishing a critical level of anti-apoptotic hepatic proteins FLIP, Bcl-2, and Bcl-xL," The Journal of Biological Chemistry, vol. 276, no. 28, pp. 26605-26613, 2001.

[138] A. Kasprzak, M. Zabel, W. Biczysko et al., "Expression of cytokines (TNF- $\alpha$, IL- $1 \alpha$, and IL-2) in chronic hepatitis c: comparative hybridocytochemical and immunocytochemical study in children and adult patients," Journal of Histochemistry and Cytochemistry, vol. 52, no. 1, pp. 29-38, 2004.

[139] K. Migita, S. Miyazoe, Y. Maeda et al., "Cytokine gene polymorphisms in Japanese patients with hepatitis B virus infectionassociation between TGF- $\beta 1$ polymorphisms and hepatocellular carcinoma," Journal of Hepatology, vol. 42, no. 4, pp. 505-510, 2005.

[140] P. Utaisincharoen, S. Ubol, N. Tangthawornchaikul, P. Chaisuriya, and S. Sirisinha, "Binding of tumour necrosis factor-alpha (TNF- $\alpha$ ) to TNF-RI induces caspase(s)-dependent apoptosis in human cholangiocarcinoma cell lines," Clinical and Experimental Immunology, vol. 116, no. 1, pp. 41-47, 1999. 


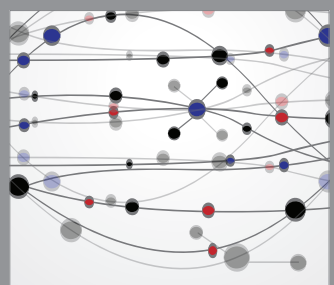

The Scientific World Journal
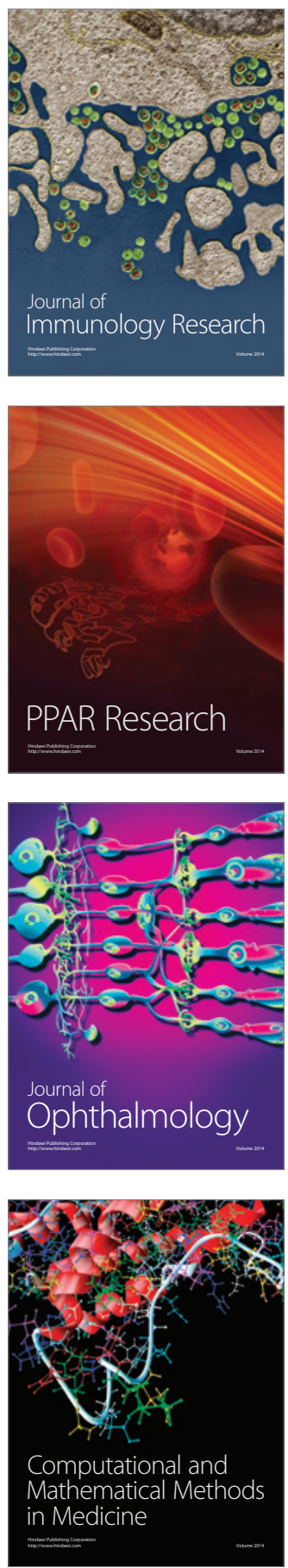

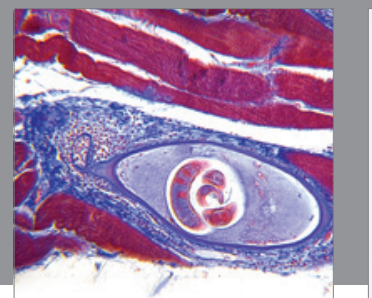

Gastroenterology

Research and Practice
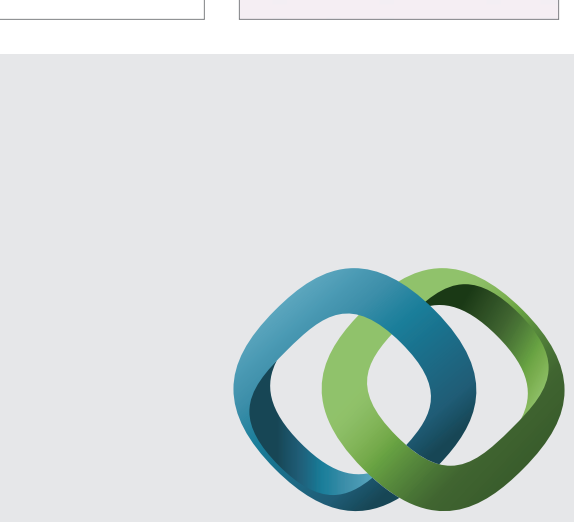

\section{Hindawi}

Submit your manuscripts at

http://www.hindawi.com
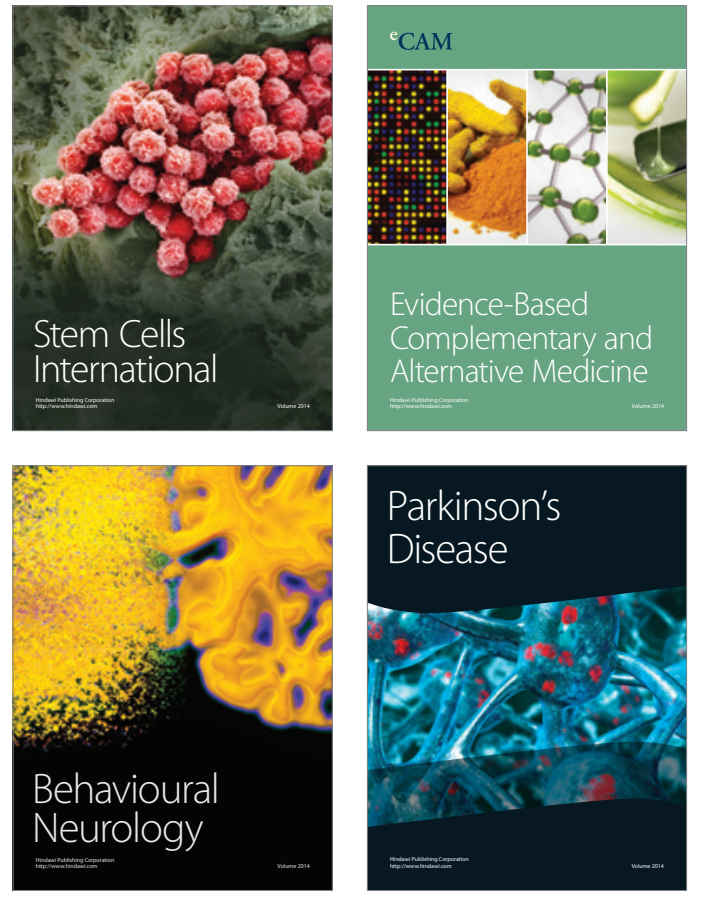
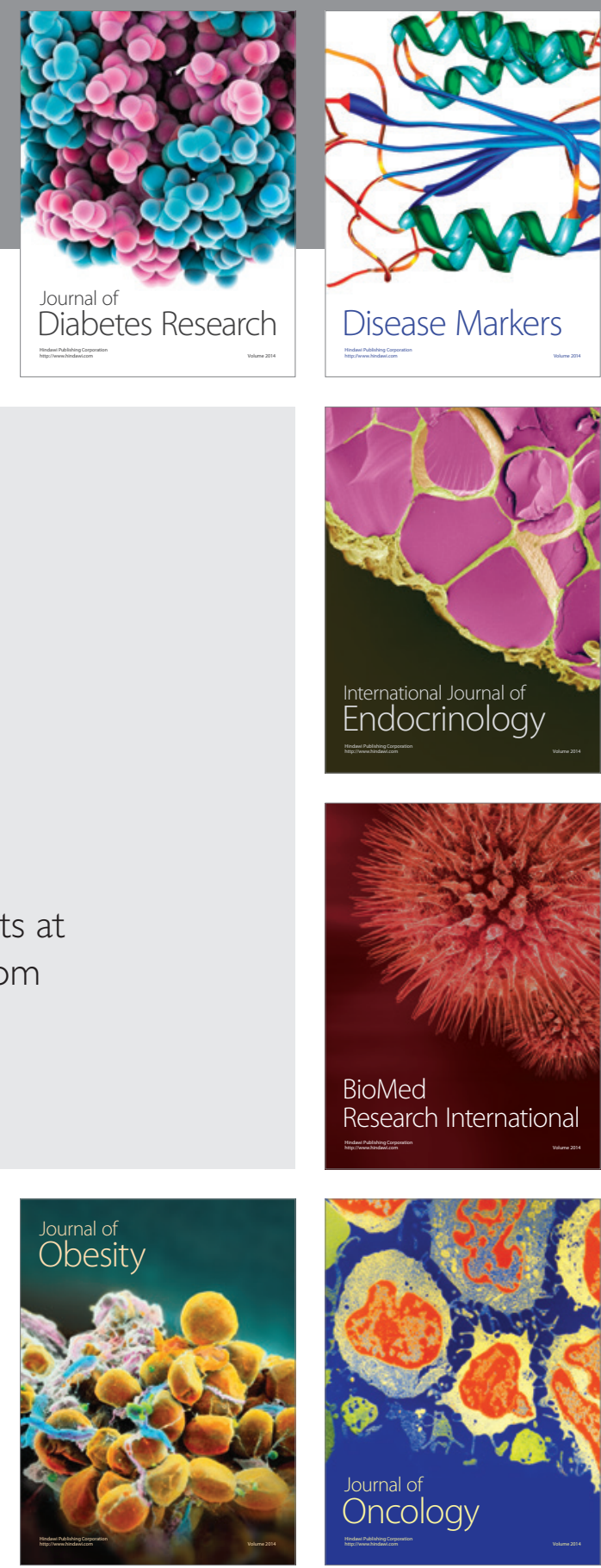

Disease Markers
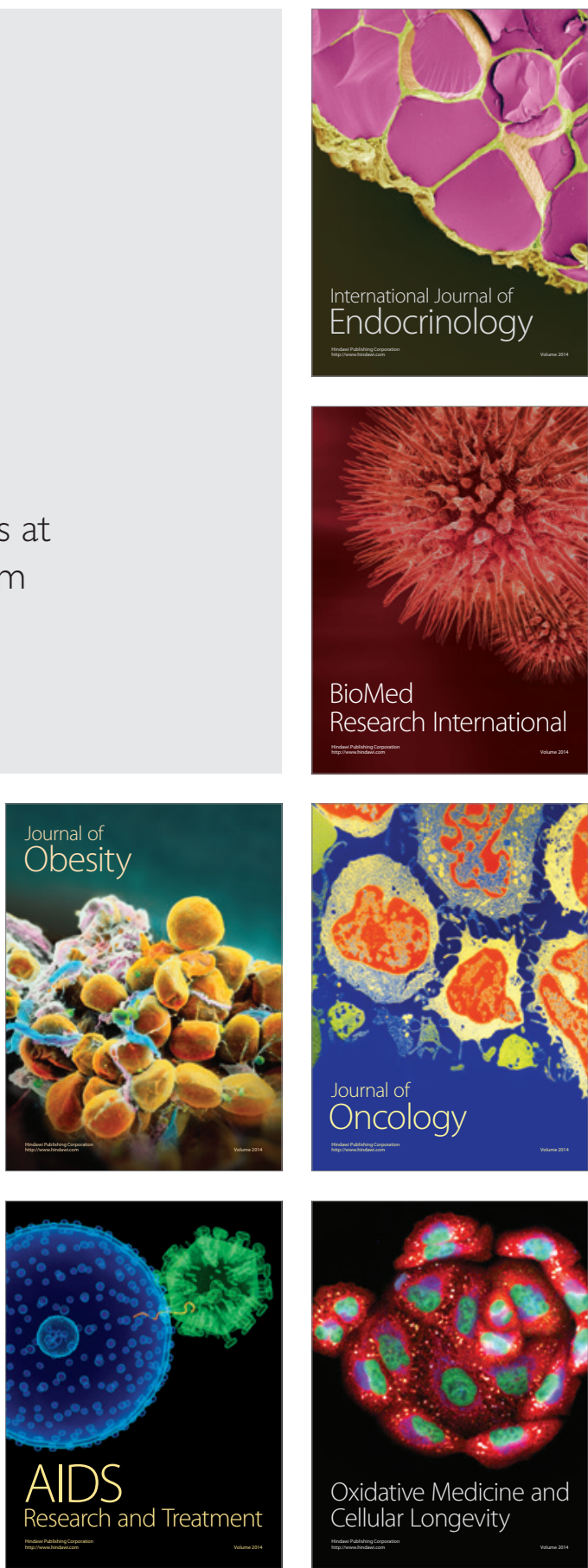